International Journal of Heritage, Tourism, and Hospitality

journal homepage: $\underline{\text { https://ijhth.journals.ekb.eg }}$

\title{
Implementation of Unified Dynamic Brand Logos of Tourism and Hotel Services as A competitive
} Advantage

Salama Ammar Mohammed ${ }^{1}$, Hammad Ali Batik ${ }^{2}$, Hany Kozmal ${ }^{* 1}$

${ }^{l}$ Higher Institute for Tourism and Hotels, Luxor (EGOTH), Egypt.

${ }^{2}$ Faculty of Tourism and Hotels, Luxor University, Egypt.

\section{ARTICLE INFO}

Keywords:

Unified Logos

Brand Logos

Tourism and Hotels Service

Brand Personality.

\begin{abstract}
This paper aims to investigate the impact of implementing a unified dynamic brand logos of tourism and hotels services are effectively and competitiveness with a competent brand personality. The study sample was 20 five and four stars of Luxor and Aswan hotels and 12 tourism companies. The study was conducted from August 2020 to February 2021. 130 questionnaire forms were received only 100 completed forms were valid (76.92\% response rate). The study found that implementation of a unified dynamic brand logos of tourism and hotels services are effective and competitive with a competent brand personality. Finding suggested that the more the guest's age the more guests' realization in the unified logo of the hotel \& tourism services. The effect of Guests' Confidence in the Unified Logo (GCUL) is equal regardless of the nationality of the guests. The study recommends that the ministry of tourism, the tourism companies, and hotels should care about Guests' Realization of the Unified Logo, and Unified Logo Strength has a significant influence on guests' purchase Intention. Promoting implementation of unified dynamic brand logos of tourism and hotel services are effective and competitiveness with a competent brand personality is mandatory. Promoting implementation of unified dynamic brand logos of tourism and hotel services are effective and competitiveness with a competent brand personality is mandatory.
\end{abstract}

C2021 Faculty of Tourism and Hotels, Fayoum University All rights reserved

\section{Introduction}

The unified logo and slogan create a distinctive brand that helps salesmen in their marketing tasks, especially in Tourism and Hotel establishments with luxurious products, by creating a value for the consumer through the logo, which becomes an essential thing for leading and leading the markets through salesmen and the unified and distinctive logo that forms a strong brand is a hero. The real in the marketing process is the ambassador of products and services.

Tourism and hotel' logos and slogans are perceived to be more unique, original, and novel; since, uniqueness, newness, and originality are concepts strongly associated with innovativeness. Stimuli that feel un- familiar because they are diffluent are perceived to be more innovative. Guest perceive

*Contact Hany Atef at: hany_atef2000@yahoo.com 
products as more innovative when information about these products is printed in difficult to read font rather than easy to read font. More complex logos could be interpreted by guests as signals of venture innovativeness. This study aims to implement unified dynamic brand logos of tourism and hotel services as a competitive advantage.

The study of Mahmood et al., (2019) recommended that future studies should pay attention to how to choose pioneering and distinctive logos to attract customers. Also recommended that future studies should focus on the logos and brands, their strength and their impact on the hearts of some tourists of different nationalities, taking into account the influence of factors the two researchers conducted an exploratory study by designing two questionnaires for hotels, tourism companies, and tourists, and after presenting them to a group of experts in the field of statistics and experts in the field of the hotel industry to determine the reliability and validity of the message.

Studies show that a brand's recall can be increased by easy-to-process brand names (Yorkston and Menon, 2004), the ease of pronunciation of the name, and how many syllables it has better not more than four (Gronau and Adjouri, 2013; Kastner, 2013). However, some places cannot choose names, as many are historical and hence inherited names. Sound branding studies also look at music associated with advertising and branding (Bronner, 2007; Palghat, 2009; Lusensky, 2010). Moreover, many researchers try to handle the logo (Pieters et al., 2010; Cian et al., 2014; Ahlers et al., 2015; seraphin.2016; Sundar and Kellaris, 2017; Baxterad and Ilicic, 2019).

The main aim of this study is the implementation of unified dynamic brand logos of tourism and hotel services as competitive advantage objectives of the study. To achieve the study goal, the study aims to the examination of the impact of the logo for services in the tourism and hotels industry on the intentions of purchasing guests for services in the tourism and hotels industry. study the relationship between the logo of the services of the tourism and hotels industry with a set of variables such as confidence in the service provider, the quality of services, and the extent of satisfaction of tourists with the prices of services.

\section{Literature review}

\subsection{Logos and slogan}

A logo is a universal visual signal and one of the most important elements establishing tourism and hotels brand. It is well recognized in the marketing literature that logos are influential visual cues, which can, for example, improve brand image and lead to more favorable brand attitudes (Zaichkowsky, 2010; Stamatogiannakis et al., 2015). Logo, slogans, illustrations, photos, and images tend to be considered low validity cues, as they could be perceived to have low or no association with venture survival and profitability in tourism and hotels (Townsend and Shu, 2010; Chan and Park, 2015). Logos and slogans in the tourism and hotels industry are the most effective intangible assets that can have a significant positive effect on the image of destinations (seraphin.2016).

There is a confusion between the concept of trademarks and the logo, it is necessary to distinguish them, a trademark is a name, term, design, symbol, or feature that defines the good or service provided by the seller as distinct from those provided by other sellers, the brand is based on major dimensions such as the image in the minds of consumers, "brand awareness" and "brand position", "perceived quality" and "brand loyalty". As for the slogan in the tourism and hotels industry, the image of the destination with all its services is easily evaluated through the slogan only and not the different and multiple brands in One tourist destination and the importance of the slogan is that it is a visual element that not only needs to be attractive but also to be representative and expressive and reflects the characteristics of the tourist destination and the quality of its hotel services (Bonnardel et al., 2020).

\subsection{Digital and Dynamic logos}

Digital, dynamic, and information-rich environments of tourism and hotels make low validity visual cues more universal and relevant than they typically are in more traditional sources of finance that rely on personal interactions. Tourism and hotels also tend to attract many guests (Agrawal et al., 2014; Burtch et al., 2015; Ahlers et al., 2015).

Dynamic logos can be interpreted by consumers as signals of social responsibility respectively (Cian et al., 2014; Sundar and Kellaris, 2017). Dynamic brand logos of tourism and hotels services are the most salient factor responsible for reputation, loyalty, quality, brand facilitating, identification, differentiation, and serving as the primary visual 
representation of destinations marketing organization image and meaning (Baxterad and Ilicic, 2019).

Contributes to a very effective and influential role in the consumption of hotels services, especially food consumption, product awareness, and intent to buy to poke the consumer, confidence, and quality, especially whenever the logo has simplicity and all the large institutions are working to develop the logo and the logo to be more attractive through redesign and a simple change in the logo and shape and there are international companies such as Pepsi, Nesiquick and Subway Brand logo (Fuciu and Hortensia, 2010).

\subsection{Logo design characteristics}

Logo design characteristics such as color and symmetry can greatly influence tourism and hotels services brand perceptions. It is also welldocumented that logos convey meaningful signals to guests, which primarily stem from their design characteristics (Labrecque and Milne, 2012, Luffarelli et al., 2018). More intricate product images are more diffluent than less intricate images. Moreover, more visually complex logos should thus be more diffluent than visually fewer complex logos (van der Lans et al., 2009; Pieters et al., 2010; Orth and Crouch, 2014; Mahmood et al., 2019).

\subsection{The role of the logo}

The role of the logo and the slogan differs in influencing the different marketing segments, especially in terms of dividing the marketing segments according to the geographical location and physiological perspective, so we find that one of the most important marketing segments is interested and fond of the logo for the services of the tourism and hotels industry, segments of East Asia, America, and England (van der Lans et al., 2009).

The tourism and hotels establishments are working hard to develop and promote their products by choosing the distinctive and unified logo and logo so that it becomes a distinctive brand and provides property rights, and the logo becomes a reference referred to in the market (Geneva, 2010).

In the field of fierce competition in the hotel industry, choosing a distinctive and unified logo and creating value for the consumer is among the main goals of any hotel and service establishment that can create the type of interaction between customers and its services by choosing the name, logo, logo, and design. Guests must be considered partners in all of the above as Hotels and tourism companies must choose a unified and distinctive slogan, which in turn leads to raising the level of satisfaction among guests and travelers (Foroudi, 2019).

\subsection{Tourism and hotels' logo}

In tourism and hotels services Logo and slogan are the most salient factor responsible for reputation, loyalty, quality, brand facilitating, identification, differentiation, and serving as the primary visual representation of destinations marketing organization (DMO) image and meaning (Alexandris et al., 2006; Baxterad and Ilicic,2019). Tourism and hotels' logos and slogans are perceived to be more unique, original, and novel; since, uniqueness, newness, and originality are concepts strongly associated with innovativeness (Garcia and Calantone, 2002; Cho, 2013; Labroo and Pocheptsova, 2016). Stimuli that feel unfamiliar because they are disfluent are perceived to be more innovative. Guests perceive products as more innovative when information about these products is printed in difficult to read font rather than easy to read font. More complex logos could be interpreted by guests as signals of venture innovativeness. Such logo complexity impacts positively guests' perceptions of undertaking tourism and hotels services (Cho and Schwarz, 2006; Sung et al., 2015).

The distinctive characteristics of the tourism and hotels industry logo, such as reputation and awareness, image, and quality, affect the decisionmaking processes of customers and guests in multidimensional forms such as the personality of the destination, the quality of its services, the ease of identification, including sincerity, excitement, and its impact on the mental image of customers for destinations and the intention to recommend. There is a close relationship between the decisive role of the slogan of the tourism and hotels industry and the understanding of guest behavior and their intention to consume, especially in food and beverage services (Annand Thomas, 2020).

In the field of fierce competition in the hotel industry, choosing a distinctive and unified logo and creating value for the consumer is among the main goals of any hotel and service establishment that can create the type of interaction between customers and its services by choosing the name, slogan, logo, and design. Guests must be 
considered partners in all of the above as Hotels and tourism companies should choose a unified and distinctive logo that in turn leads to raising the level of satisfaction among guests and travelers. In the field of the hotel's industry, the logo is one of the most important intangible assets that increase the assets of hotels and contributes to attracting customers, for example, the hotel's industry in England is considered one of the highest services and the guests did not see the hotel services before booking, depending on the brand value, trust and quality. In the tourism industry, there were 40 million tourists in 2018 that were the first time to visit England because of the brand's value, awareness, and reputation (Foroudi, 2019).

The most early-stage entrepreneurial venture has a logo and investors have been found to react to visual signs (Chan and Park, 2015). Logos are low validity cues because their design does not provide information about a venture's underlying quality and has low or no perceived association with venture survival and profitability. Yet, the perceptions and funding decisions of backers might be influenced by logos because logos are particularly salient and ubiquitous on the landing pages of tourism and hotels platforms and campaigns. Also, logos are processed quickly and automatically, which could facilitate the identification and differentiation of ventures (Zaichkowsky, 2010; Scheaf et al., 2018). Backers likely use the logo design as an experiential to facilitate venture evaluations (Chan et al., 2018).

\subsection{Logo impact on guests' perceptions}

The logo is likely to have a positive impact on guests' perceptions and funding decisions because guests, who are time-constrained and overloaded with information, might rely on logos as a means to fulfill their specific goal of finding a suitable venture to invest in. Of particular interest to us is the potential existence of a positive link between processing dissiliency and innovativeness. Processing fluency is known to be strongly associated with a feeling of familiarity while processing resiliency is associated with a feeling of unfamiliarity (Oppenheimer, 2008; Alter and Oppenheimer, 2009; Labroo and Pocheptsova, 2016).

\subsection{Logo impact Tourism and hotels' brand}

In tourism and hotels brand is a network of the product and services formed in the guest's mind, and those that matter to the future of the place are developed from the visual, verbal, and behavioral expression of a place (Braun et.al. 2013). One challenge for managing a place brand representing a city or a country is which image stands out or will have the most appeal or salience across consumers of specific products. It has been found that a novel brand's recall can be increased through an intriguing logo design. Images are modified by place advertising (induced image) with the last stage forming a complex image based on a combination of the previous two images (Hankinson, 2004; Balakrishna et al., 2011), can also change through the various decision-making stages as hypothesized by (Plassman, Ramsøy, and Milasavljevic, 2012) or across stakeholders (Hankinson, 2004a, Kotsi et al., 2018).

Auditory signatures, logos, and slogans are more than brand names. Music can be associated with a brands' uniqueness (Kemp et al., 2012) and sounds can have an impact on brand meaning (Klink and $\mathrm{Wu}, 2014)$.

There is a distinction between different types of tourism and hotels establishments with branding like in the category of brand sounds (jingles, sound logos, brand soundscapes, and themes), and sound identity (which need not include music) which is developed specifically for the brand compared to music collaboration, including compilations, music sponsoring and events, and product/brand name placement (Kilian, 2007; Andersson, 2009). There needs to be as much depth in strategy for the audio logo as for the visual logo (Fahey 2014; Kotsi et al., 2018).

Brand value is facilitated by strong communication that delivers the value proposition. Though the perceptions of host destination images are often vague, due to ignorance or misconception, this also represents a great opportunity to title a unique identity (O'Shaughnessy \& O'Shaughnessy, 2000). In tourism and hotels, the intangible value of a brand is about $40-45 \%$ of company value (Brand Finance, 2012).

This makes a study of a place brand, its communication, and the perceptions of it in terms of tourism and hotels images of potential interest for academia and practitioners alike. Existing studies in logo and brand communication focus on slogans, taglines, and visuals (Ashworth and Kavaratzis, 2009). Brands are pieces of information, meanings, experiences, emotions, images, logos, slogans, and intentions 
interconnected by neural links of varying strength (Lindstrom, 2005; Kotsi et al., 2018).

Most tourism and hotel brand communication focus on two senses sight and sound - but most brand studies center on the visual, and sound studies are rare (Bartholme and Melewar, 2009; Kotsi et al., 2018).

Depending on that, the research hypotheses are:

H1: There are no statistically significant differences between age categories concerning guests' confidence in the Unified Logo of the hotels \& tourism services.

$\mathrm{H} 2$ : There are no statistically significant differences between age categories regarding

\section{Figure 1}

Conceptual framework: guests' realization of the unified logo of the hotels \& tourism services.

H3: There are no statistically significant differences between nationality categories concerning guests' confidence in the unified logo of the hotels \& tourism services.

H4: There are no statistically significant differences between nationality categories about guests' realization of the unified logo of the hotels \& tourism services.

H5: There is no statistically significant effect of the unified logo dimensions guests' purchase intention.

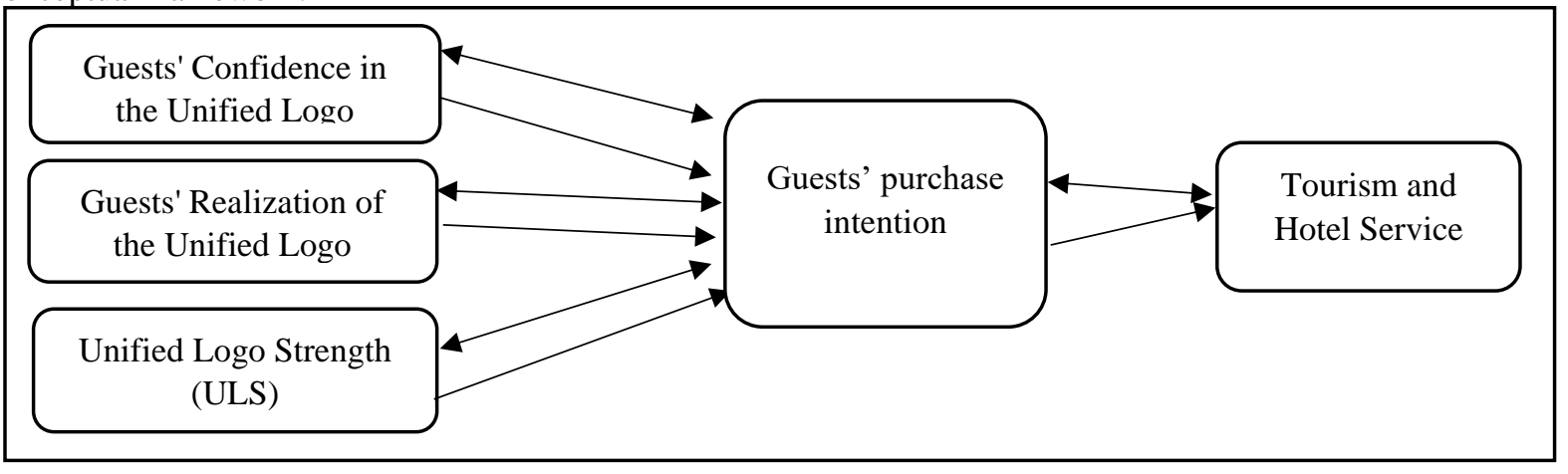

\section{Methodology}

Questionnaires provide an efficient way of collecting a large amount of data from a sizable population of tourists in Egypt in a highly economical way. The questionnaire consists of four Axes: The first axis discusses Guests' Confidence in the Unified Logo (Foroudi, 2019). The Second axis: Purchase intention (Geneva, 2010), the third axis: Guests' Realization of the unified logo (Sundar and Kellaris, 2017), the fourth axis Logo strength (Luffarelli et al., 2018).

A pilot study was conducted in this study from July to 2020. The pilot study aimed to find out the implementation of unified dynamic brand logos of tourism and hotels services is effective and competitive with a competent brand personality. a pilot study was made through two questionnaires, one of which included a group of 20 five and four stars of Luxor and Aswan hotels and the number of 12 tourism companies at the same hotels, and after collecting and analyzing data on a program, several results were reached, the most important of which is that $90 \%$ of hotels, $85 \%$ of tourism companies do not pay much attention to the logos of their services, and through the tourists' questionnaire it became clear that one of the most important results is that $95 \%$ of the total tourists they are dispersed due to crowding and multiple logos of tourism and hotels services, which does not give a unified picture of industry services, $90 \%$ of total tourists the logo affects their choice and purchase decision. Hotels are tourism, 95\% of tourists

Moreover, to ensure that the survey was well designed and easily understood by potential respondents, to examine the reliability and validity of the research tools as well as to develop and refine measure of the questions. The questionnaire was reviewed by 8 academic scholars from tourism and hotel management departments to establish their appropriateness, clarity and to ease the understanding. Some alterations were suggested and then were implemented. The questionnaire was then pre-tested to investigate the respondent's understanding of scale items and to identify also any issues that were complex or confusing to develop appropriate scale items to ensure the validity and reliability of the research. For this purpose, a questionnaire was distributed to a sample of the hotels and the tourism companies' 
customers. Several 25 forms were distributed to respondents who were asked to complete them.

The study target sample was 20 five and four stars of Luxor and Aswan hotels and 12 tourism companies in the same hotel's sample. The study was conducted from August 2020 to February 2021. 130 questionnaire forms were received only 100 completed forms were valid (76.92\% response rate). The target population for this study was questionnaires were conducted with the customer.
The collected data were analyzed using SPSS version 20.

The study was conducted on a sample of the study target 'sample was 20 five and four stars of Luxor and Aswan hotels and 12 tourism companies in the same hotel's sample. The choice of the hotels was due to category and the more availability. The characteristics of the investigated hotels are as follows in table 1 .

Table 1

The Characteristics of the Investigated Hotels.

\begin{tabular}{|c|c|c|c|}
\hline Hotel name & Total Rooms & Category & Location \\
\hline Hilton Luxor Hotel and SPA & 236 & \multirow{7}{*}{5 stars } & \multirow{12}{*}{ Luxor } \\
\hline Luxor Sheraton Hotel Resort & 290 & & \\
\hline Maritim Jolie Ville Kings Resort & 334 & & \\
\hline Sofitel Karnak Hotel & 347 & & \\
\hline Sofitel Winter Palace Hotel & 234 & & \\
\hline Sonesta st. George Hotel Luxor & 322 & & \\
\hline Steigen Bergernile Palace Hotel & 304 & & \\
\hline Akhetaton Village & 144 & \multirow{5}{*}{4 stars } & \\
\hline Almoudira Hotel & 54 & & \\
\hline El Luxor Hotel & 306 & & \\
\hline Iberotel Luxor Hotel & 185 & & \\
\hline Pyramisa Isis Luxor Hotel & 480+time share & & \\
\hline Amoun Village & 50 & \multirow{5}{*}{5 stars } & \multirow{8}{*}{ Aswan } \\
\hline Mövenpick Resort Aswan & 244 & & \\
\hline New Cataract Hotel & 62 & & \\
\hline Pyramisa Isis Island Hotel & 447+time share & & \\
\hline Sofitel Old Cataract Hotel & 76 & & \\
\hline Basma Hotel Aswan & 210 & \multirow{3}{*}{4 stars } & \\
\hline Cleopatra Hotel & 130 & & \\
\hline Isis Hotel Aswan & 104 & & \\
\hline
\end{tabular}

\subsection{Validity of the research}

The four factors were Guests' Realization of the Unified Logo (GRUL), Purchase Intention (PI), Guests' Realization of the Unified Logo (GRUL), and Unified Logo Strength (ULS). The 20 items in the survey, the items $(3,9,14,15,16)$ were categorized as GCUL, the items $(4,6,10)$ were categorized as PI, the items $(1,5,7,8,17,19,20)$ were categorized as GRUL, and the items $(2,11$, $12,13,18$ ) were categorized as LS (Hair et al., 2009). The KMO test was 0.64 referring to a meritorious level based on Kaiser and Rice (1974) and Bartlett's test was significant $(\chi 2=551.113, \mathrm{p}$ $=0.000)$. The previous four factors explain $55.3 \%$ of the total variance of the main viable of the research (Kaiser and Rice, 1974).

\subsection{Reliability of the research}

Table 2

Reliability analysis of the independent variables used in the research

\begin{tabular}{|l|c|c|}
\hline \multicolumn{1}{|c|}{ The Axis } & $\begin{array}{c}\text { No. of } \\
\text { statements }\end{array}$ & $\begin{array}{c}\text { Alpha } \\
\text { Coefficient }\end{array}$ \\
\hline $\begin{array}{l}\text { Guests' Confidence in } \\
\text { the Unified Logo }\end{array}$ & 5 & 0.80 \\
\hline Purchase intention & 3 & 0.76 \\
\hline $\begin{array}{l}\text { Guests' Realization of } \\
\text { the unified logo }\end{array}$ & 7 & 0.93 \\
\hline Logo strength & 5 & 0.77 \\
\hline
\end{tabular}

Cronbach's $\alpha$ values of all variables of the research exceeded 0.70, suggesting suitable measurement reliability. Cronbach's $\alpha$ value of more than 0.7 is good for reliability (Hair et al., 2010).

\section{Findings and Discussion}


Table 3

The sample characteristics

\begin{tabular}{|l|c|c|c|}
\hline Variable & Sample & No. & Percentage (\%) \\
\hline \multirow{4}{*}{ Age } & $20-30$ & 57 & 57 \\
\cline { 2 - 4 } & $>30-40$ & 21 & 21 \\
\cline { 2 - 4 } & $>40-50$ & 14 & 14 \\
\cline { 2 - 4 } & $>50$ & 8 & 8 \\
\hline \multirow{5}{*}{ Education Level } & Bachelor & 53 & 53 \\
\cline { 2 - 4 } & Master & 33 & 33 \\
\cline { 2 - 4 } & Ph.D. Degree & 14 & 25 \\
\hline \multirow{3}{*}{ Nationality } & Egyptian & 25 & 29 \\
\cline { 2 - 4 } & Arabs & 29 & 46 \\
\cline { 2 - 4 } & Foreigners & 46 & \\
\hline
\end{tabular}

\subsection{Descriptive statistics}

\subsubsection{Guests' Confidence in the Unified Logo (GCUL)}

Table 4 referred that the unified logo is a part of the value of the tourism and hotels industry services, and it comes at a first rank $(\mathrm{M}=3.86, S D=1.005)$, followed by "A unified slogan can engrave the services provided in consumers' memories" $(\mathrm{M}=$ 3.65, $S D=1.038)$. On the other hand, "A unified logo creates trust and loyalty for the services provided" is ranked last variable $(\mathrm{M}=1.96, S D=$ 1.17). The overall mean (2.89) reflects the low level of consumer confidence in the tourism and hotels industry services

Table 4:

Statistics for guests' confidence in the unified logo

\begin{tabular}{|c|c|c|c|}
\hline Statements & M & SD & Rank \\
\hline $\begin{array}{l}\text { The logo helps you to make your first impression on the services of the tourism and } \\
\text { hotels industry }\end{array}$ & 1.96 & 1.17 & 4 \\
\hline A unified logo creates trust and loyalty for the services provided & 1.95 & 1.21 & 5 \\
\hline The unified logo is a part of the value of the tourism and hotels industry services & 3.86 & 1.005 & 1 \\
\hline A unified slogan can engrave the services provided in consumers' memories & 3.65 & 1.038 & 2 \\
\hline $\begin{array}{l}\text { The unified logo for the services of the tourism and hotels industry is conveyed and } \\
\text { communicated to friends by the word of mouth. }\end{array}$ & 3.06 & 1.023 & 3 \\
\hline Grand mean & 2.89 & & \\
\hline
\end{tabular}

\subsubsection{Purchase intention (PI)}

Table 5 showed that the unified logo affects the volume of consumption of services in the tourism and hotel industry" comes at a first rank $(\mathrm{M}=2.5$, $\mathrm{SD}=0.91)$, followed by "The impact of the tourism and hotel industry services' logo on your purchase decision" ( $\mathrm{M}=2.18, \mathrm{SD}=1.12)$. On the other hand, the $\log 0$ of the services of the tourism and hotel industry contributes to an increase in the consumption of the services is ranked last variable $(\mathrm{M}=1.2, \mathrm{SD}=0.53)$. The overall mean (1.96) reflects the low level of customers' purchase intention of the tourism and hotel industry services.

\section{Table 5}

Statistics for purchase intention

\begin{tabular}{|l|c|c|c|}
\hline Statements & M & SD & Rank \\
\hline The impact of the tourism and hotels industry services' logo on your purchase decision & 2.18 & 1.12 & 2 \\
\hline $\begin{array}{l}\text { The logo of the services of the tourism and hotel industry contributes to an increase } \\
\text { in the consumption of the services }\end{array}$ & 1.2 & 0.53 & 3 \\
\hline $\begin{array}{l}\text { The unified logo affects the volume of consumption of services in the tourism and } \\
\text { hotel industry }\end{array}$ & 2.5 & $.91 \cdot$ & 1 \\
\hline \multicolumn{1}{|c|}{ Grand mean } & $\mathbf{1 . 9 6}$ & & \\
\hline
\end{tabular}




\subsubsection{Guests' Realization of the Unified Logo (GRUL)}

Table 6 showed that "The unified logo plays a very important role in the service reputation of the tourism and hotel industry" comes at a first rank $(\mathrm{M}=4.5, \mathrm{SD}=0.5)$, followed by "Your satisfaction with the services provided by the tourism and hotel industry in Egypt" (M=3.87, SD=1.13). On the other hand, "The extent of your interest in the logo of tourism and hotel industry services" $(\mathrm{M}=$ $1.62, \mathrm{SD}=0.85$ ) and "I prefer having a unified logo for services in the tourism and hotel industry" $(\mathrm{M}=1.58, \mathrm{SD}=0.96)$ are ranked last variables respectively. The overall mean (2.75) reflects the low level of customers' realization of the unified logo of the tourism and hotel industry services

\section{Table 6}

Statistics for guests' realization of the unified logo

\begin{tabular}{|c|c|c|c|}
\hline Statements & M & SD & Rank \\
\hline The extent of your interest in the logo of tourism and hotel industry services & 1.62 & 0.85 & 6 \\
\hline The logo of the tourism and hotel industry helps paint a mental picture for me & 1.86 & 1.20 & 5 \\
\hline I prefer having a unified logo for services in the tourism and hotel industry & 1.58 & 0.96 & 7 \\
\hline $\begin{array}{l}\text { The unified logo plays a very important role in the service reputation of the tourism and } \\
\text { hotel industry }\end{array}$ & 2.23 & 1.42 & 4 \\
\hline $\begin{array}{l}\text { Consumer behavior in tourism and hotels services depend on the extent of trust, belief, } \\
\text { and association with these services }\end{array}$ & 3.60 & 1.12 & 3 \\
\hline The attractiveness and excitement of the logo of tourism and hotels services to me & 4.50 & 0.50 & 1 \\
\hline Your satisfaction with the services provided by the tourism and hotel industry in Egypt & 3.87 & 1.13 & 2 \\
\hline Grand mean & 2.7541 & & \\
\hline
\end{tabular}

\subsubsection{Unified Logo Strength (ULS)}

The next table indicated that A unified logo is more attractive and reliable than multiple logos" comes at a first rank $(\mathrm{M}=3.9, \mathrm{SD}=1.06)$, followed by "Engraving the logo in the minds is linked to familiarity, recognition, and connection with it"
$(\mathrm{M}=3.38, \mathrm{SD}=1.08)$. On the other hand, "The unified logo for the services of the tourism and hotel industry gives an advance picture of the quality of services" is ranked last variable $(\mathrm{M}=$ $1.42, \mathrm{SD}=0.606)$. The overall mean (2.47) reflects the low level of logo strength of the tourism and hotel industry services.

Table 7

Statistics for Unified logo strength

\begin{tabular}{|c|c|c|c|}
\hline Statements & $\mathbf{M}$ & SD & Rank \\
\hline The logo of the tourism and hotel industry services has a positive and effective effect & 2.05 & 1.13 & 3 \\
\hline $\begin{array}{l}\text { The unified logo for the services of the tourism and hotel industry gives an advanced } \\
\text { picture of the quality of services }\end{array}$ & 1.42 & 0.606 & 5 \\
\hline $\begin{array}{l}\text { The unified logo creates a level of satisfaction with the prices of services in the tourism } \\
\text { and hotel industry }\end{array}$ & 1.60 & 0.68 & 4 \\
\hline A unified logo is more attractive and reliable than multiple logos & 3.90 & 1.06 & 1 \\
\hline Engraving the logo in the mind is linked to familiarity, recognition, and connection with it & 3.38 & 1.08 & 2 \\
\hline Grand mean & 2.47 & & \\
\hline
\end{tabular}

\subsection{Test of hypotheses}

To test the first hypothesis of the research, the Kruska-Wallis test was used, Kruska-Wallis test used if the study has scale variables and nominal variables, it tests whether the mean ranks are similar in all the groups (McDonald, J, 2014). The findings showed as follow:

Table 8:

Significant differences between age categories regarding GCUL

\begin{tabular}{|l|l|l|l|l|}
\hline Variable Age categories & \multicolumn{1}{|c|}{ No. } & \multicolumn{1}{c|}{ Mean Rank } & Chi-Square & \multicolumn{1}{c|}{ Sig. } \\
\hline GCUL 20-30 & 57 & 39.71 & 19.85 & 0.000 \\
\cline { 1 - 3 }$>30-40$ & 21 & 69.38 & & \\
\hline
\end{tabular}




\begin{tabular}{|l|l|l|l|l|}
\hline$>50$ & 8 & 61.56 & & \\
\hline
\end{tabular}

From the previous table, it showed that sig. value is $(0.000)$ which means that there are significant differences between the age categories about guests' confidence in the unified logo (GCUL). The findings of Mann-Whitney tests indicated that there are no statistically significant differences between each pair of all age categories except the category of (20-30); this result indicated that the more the guest's age the more guests' confidence in the unified logo of the hotel \& tourism services. This result referred that the first hypothesis of the research was not accepted.

To test the second hypothesis of the research, the Kruska-Wallis test was used. The results showed as follow:

Table 9

Significant differences between age categories regarding GRUL

\begin{tabular}{|l|l|l|l|c|}
\hline Variable Age categories & No. & Mean Rank & Chi-Square & Sig. \\
\hline GCUL $\mathbf{2 0 - 3 0}$ & 57 & 41.05 & \multirow{2}{*}{16.45} & \multirow{2}{*}{0.001} \\
\cline { 1 - 3 } & 21 & 67.05 & \\
\cline { 1 - 3 } & 14 & 53.68 & & \\
\cline { 1 - 2 } & 8 & 68.81 & & \\
\hline
\end{tabular}

From the previous table, it showed that sig. value is $(0.001)$ which means that there are significant differences between the age categories regarding guests' realization of the unified logo (GRUL) of the hotel \& tourism services. The findings of Mann-Whitney tests indicated that there are no statistically significant differences between each pair of all age categories except the category of (20-
30); this finding suggested that the more the guest's age the more guests' realization in the unified logo of the hotel \& tourism services. This result referred that the second hypothesis of the research was not accepted.

To test the third hypothesis of the research, the Kruska-Wallis test was used. The results showed as follow:

Table 10

Statistical significant differences between nationality categories regarding GCUL

\begin{tabular}{|l|l|l|l|c|}
\hline Variable Age categories & No. & Mean Rank & Chi-Square & Sig. \\
\cline { 1 - 3 } GCUL Egyptian & 25 & 48.12 & 2.093 & 0.351 \\
\cline { 1 - 3 } Arabs & 29 & 45.6 & & \\
\hline
\end{tabular}

From the previous table, it showed that sig. value is $(0.351)$ which means that there are no significant differences between the nationality categories about guests' confidence in the unified logo (GCUL) of the hotel \& tourism services. This finding confirms that the effect of GCUL is equal regardless of the nationality of the guests. This result referred that the third hypothesis of the research was accepted.

To test the fourth hypothesis of the research, the Kruska-Wallis test was used. The results showed as follow:

\section{Table 11}

Statistical significant differences between nationality categories about GRUL

\begin{tabular}{|l|l|l|l|c|}
\hline Variable Age categories & No. & Mean Rank & Chi-Square & Sig. \\
\hline GCUL Egyptian & 25 & 51.68 & \multirow{2}{*}{15.40} & 0.000 \\
\cline { 1 - 3 } Arabs & 29 & 33.69 & & \\
\cline { 1 - 3 } Foreigners & 46 & 60.46 & & \\
\hline
\end{tabular}

From the previous table, it showed that sig. value is $(0.000)$ which means that there are significant differences between the nationality categories about guests' realization in the unified logo
(GRUL) of the hotel \& tourism services. The findings of Mann-Whitney tests indicated that these differences were favored the Foreigners. This 
result referred that the fourth hypothesis of the research was not accepted.

To test the fifth hypothesis of the research, multiple regression coefficients were used to determine the influence of GCUL, GRUL, and ULS on guests' purchase intention, the results showed as follow:

Table 12

Multiple regression coefficients for the influence of GCUL, GRUL, and ULS on guests' purchase intention

\begin{tabular}{|c|c|c|c|c|c|}
\hline Model & $\mathbf{R}$ & $\mathbf{R}^{2}$ & Beta & $T$ & ANOVA Sig. \\
\hline Constant & \multirow{4}{*}{0.454} & \multirow{4}{*}{0.206} & 0.532 & 1.215 & \multirow[t]{4}{*}{0.000} \\
\hline GCUL & & & 0.275 & 2.322 & \\
\hline GRUL & & & 0.176 & 1.714 & \\
\hline ULS & & & 0.084 & 0.829 & \\
\hline
\end{tabular}

From tables (12), it showed that $(\mathrm{R})$ value $(0.454)$ referred that there is a median degree of correlation between GCUL, GRUL, and ULS, as well as the coefficient of determination $\left(\mathrm{R}^{2}\right)$, is $(0.206)$, suggesting that $20.6 \%$ of the variation of intended guests' purchase intention was explained by independent variables. ANOVA Sig. (0.000) indicated that GCUL, GRUL, and ULS have a significant influence on guests' purchase intention. This result referred that the fifth hypothesis of the research was not accepted. The following equation can be inferred to predict the guests' purchase intention from independent variables (GCUL, GRUL, and ULS) as follow:

The regression equation 1: The influences of GCUL, GRUL, and ULS on the guests' purchase intention

$\mathrm{PI}=0.275 \mathrm{GCUL}+0.176 \mathrm{GRUL}+0.084 \mathrm{ULS}+$ 0.532

\section{The study model}

From the results of table (12) it can be suggested the following model:

\section{Figure 2: The study model}

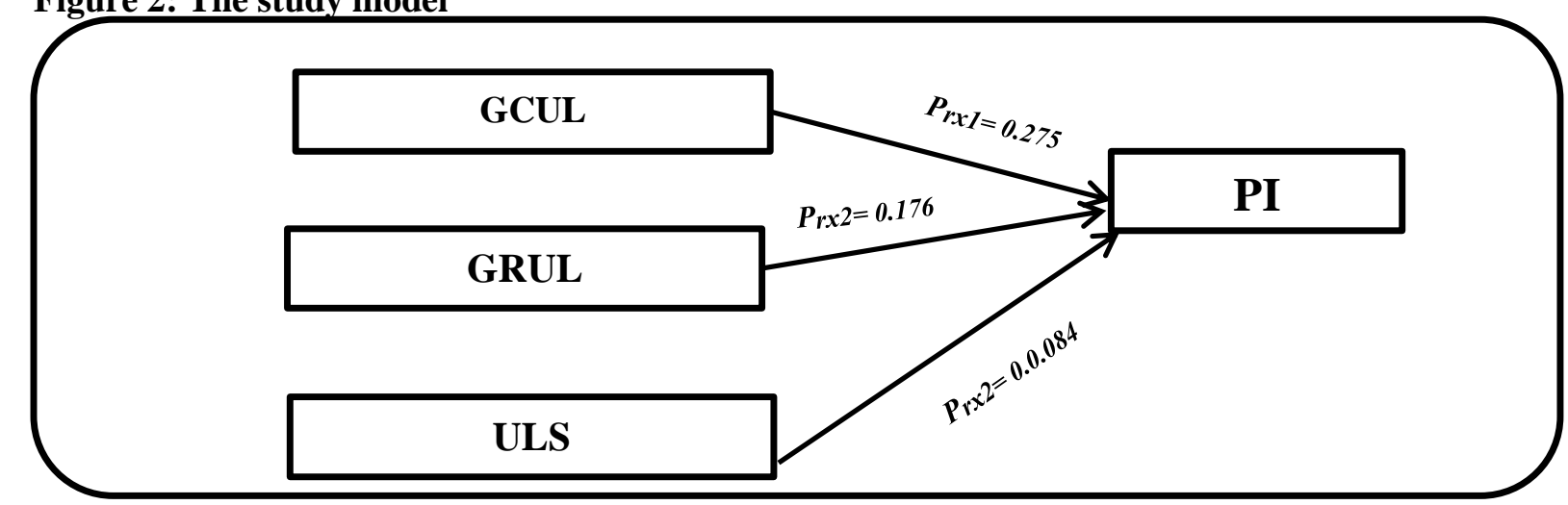

\section{Discussion}

The study found that implementation of a unified dynamic brand logos of tourism and hotels services are effective and competitive with a competent brand personality this result agrees with "Lindstrom, 2005; Palghat, 2009; Lusensky, 2010; Kemp et al., 2012; Governs, 2012; Luffarelli et al., 2018). On the other hand, the study assured that result indicated that the more the guest's age the more guests' confidence in the unified logo of the hotel $\&$ tourism services. Finding suggested that the more the guest's age the more guests' realization in the unified logo of the hotel \& tourism services this result agree with "Geneva, 2010; Foroudi, 2019”.
Moreover, the effect of GCUL is equal regardless of the nationality of the guests. The findings of Mann-Whitney tests indicated that these differences were favored the Foreigners. GCUL, GRUL, and ULS have a significant influence on guests' purchase intention this result agrees with "Geneva, 2010; Alexandris et al., 2006; Baxterad and Ilicic, 2019".

\section{Recommendations and Implication}

Recommendations for the ministry of tourism, the tourism companies, and hotels concerning the development of the implementation of unified dynamic brand logos of tourism and hotels services are effectively and competit with a competent brand personality in Egypt 
1. Enhancing the unified dynamic brand logos of tourism and hotels services concept in Egypt.

2. Providing a legislative framework to organize the brand personality in theptianive tourism and hotels services.

3. Raising awareness towards the implementation of unified dynamic brand logos of tourism and hotels services are effective and competitiveness with a competent brand personality.

4. Supporting the co-operation between tourist organizations to put a set of criteria to ensure the quality of implementation unified dynamic brand logos of tourism and hotels services are effectively and competitiveness with a competent brand personality.

Recommendations concerning the development of brand personality in Egypt

1. Continuous development for unified dynamic brand logos of tourism and hotels services.

2. Keeping pace with technological changes is mandatory for brand personality.

3. Promoting implementation of unified dynamic brand logos of tourism and hotels services are effective and competitiveness with a competent brand personality is mandatory.

\section{Implications}

This study is suggested more studies towards the implementation of unified dynamic brand logos of hotels and tourism companies. Future studies could focus on other destinations such as Sharm el-sheik, Hurghada, Cairo. The study focuses on hotels and tourism' companies' future studies could focus on other categories of hospitality establishments and food services. Moreover, could experiment with the study model.

\section{References:}

Agrawal, A., Catalina, C., Goldfarb, A. (2014). Some simple economics of crowdfunding. In: Innovation Policy and the Economy. 14(1). pp. 63-97.

Agrawal, A., Catalina, C., Goldfarb, A. (2016). Are syndicates the killer app of equity crowdfunding? Calif. Manag. Rev. 58 (2), 111-124.

Ahlers, G.K., Cumming, D., Gunther, C., Schweitzer, D., (2015). Signaling in equity crowdfunding. Entrep. Theory Pract. 39 (4), 955-980.

Ahn, J., \& Thomas, T. K. (2020). The role of customers' perceived values of integrated resort brands in the destination. Journal of Destination Marketing \& Management, 15, 1-22.

Alexandris, K., Kouthouris, C., \& Meligdis, A. (2006). Increasing customers' loyalty in a skiing resort: The contribution of place attachment and service quality. International Journal of Contemporary Hospitality Management, 18(5), 414-425.

Alter, A.L., Oppenheimer, D.M. (2009). Uniting the tribes of fluency to form a metacognitive nation. Personal. Soc. Psychol. Rev. 13 (3), 219-235.

Andersson, M., \& Ekman, P. (2009). Ambassador networks and place branding. Journal of Place Management and Development, 2(1), 41-51.

Ashworth, G. J., \& Kavaratzis, M. (2009). Beyond the logo: Brand management for cities. Journal of Brand Management, 16(8), 520-531. https://www.researchgate.net/publication/3037031 36_Viral_marketing__how_to_use_the_Internet_for_advertising.

Baker, H.K., Nofsinger, J.R., 2002. Financial services. Review 11 (2), 97-116.

Balakrishnan, S., Nekhili, R., \& Lewis, C. (2011). Destination brand components. International Journal of Culture, Tourism and Hospitality Research, 5(1), 4-25.

Baxter, S. M., \& Ilicic, J. (2018). May the force drag your dynamic logo: The brand work-energy effect? International Journal of Research in Marketing, 35(3), 509-523.

Bonnardel, V., Séraphin, H., Gowreesunkar, V., \& Ambaye, M. (2020). Empirical evaluation of the new Haiti DMO logo: Visual aesthetics, identity and communication implications. Journal of Destination Marketing \& Management, 15, 2-25.

Brand Finance (2012). Available: 〈http://brandfinance.com/images/upload/best_glob al_banking_brands_2012_dp.pdf $\rangle$ Accessed 12.10.2020.

Braun, E., Kavaratzis, M., \& Zenker, S. (2013). My city - my brand: The different roles of residents in place branding. Journal of Place Management and Development, 6 (1), 18-28.

Braun, E., Kavaratzis, M., \& Zenker, S. (2013). My city - my brand: The different roles of residents in place branding. Journal of Place Management and Development, 6 (1), 18-28.

Chan, C.R., Parhankangas, A. (2017). Crowdfunding innovative ideas: how incremental and radical innovativeness influence funding outcomes. Entrep. Theory Pract. 41, (2). 237-263.

Chan, C.R., Park, H.D. (2013). The influence of dispositional affect and cognition on venture investment portfolio concentration. J. Bus. Ventur. 28 (3), 397-412.

Cian, L., Krishna, A., Elder, R.S. (2014). This logo moves me: dynamic imagery from static images. J. Mark. Res. 51 (2), 184-197.

Fahey, C. (2014). Beyond jingles and needle drops: What every brand needs to know about audio branding's power to persuade. Journal of Brand Strategy, 2(4), 347-354. 
Foroudi, P. (2019). Influence of brand signature, brand awareness, brand attitude, brand reputation on hotel industry's brand performance. International journal of hospitality management, 76, 271-285p.272.

Fuciu, M., \& Hortensia, G. (2010).Viral marketing how to use the Internet for advertising. Publication at:

https://www.researchgate.net/publication/3037031 36.

Geneva, (2010). Developments and challenges in the tourism and hospitality sector Issues paper for discussion at the Global Dialogue Forum for the Hotels, Catering, Tourism Sector (23-24 November 2010) Geneva, 2010). International Labour Organization Sectoral Activities Programme. ISBN 978-92-2-123947-5 (print); ISBN 978-92-2123948-2 (Web pdf).

Govers, R. (2012). Brand Dubai, and its competitors in the Middle East: An image and reputation analysis. Place Branding and Public Diplomacy, 8(1), 48-57.

Gronau, W., \& Adjouri, N. (Eds.). (2013). Branded spaces: Experience enactments and entanglements. Germany: Springer VS, 23-41.

Hair, J.F., Anderson, R.E., Black, W.C., Babin, B.J. (2009), "Multivariate Data Analyses", $7^{\text {th }}$ edition.

Hair, J.F., Black, W.C., Babin, B.J. and Anderson, R.E. (2010), "Multivariate Data Analysis", $7^{\text {th }}$ ed., Prentice Hall, Upper Saddle River, NJ.137-146.

Henderson, P. W., Giese, J. L., \& Cote, J. A. (2004). Impression management using typeface design. Journal of Marketing, 68(4), 60-72.

Kaiser, H.F. and Rice, J. (1974). Little Jiffy, Mark IV, Educational and Psychology measurement, 34, 111-117.

Kastner, S. (2013). Heimatkalange: The conceptual design of branded spaces by means of sonic branding In: S. Sonnenburg, \& L. Baker (Eds.), Branded Spaces: Experience enactments and entanglements (pp. 167-177).

Kemp, E., Childers, Y., \& Williams, H. (2012). Place branding: Creating self- brand connections and brand advocacy. Journal of Product \& Brand Manage- ment, 21(7), 508-515.

Kilian, K. (2007). From brand identity to audio branding. K. Bronner \& R. Hirt (Eds.). Audio branding - brands, sound and communication, Nomos: Baden-Baden. 35- 48.

Klink, R. R., \& Wu, L. (2014). The role of position, type, and combination of sound symbolism imbeds in brand names. Marketing Letters, 25(1), 13-24.

Kotsi, F; Balakrishnan, M; Michael, I; Ramsøy, T, (2018), Place branding: Aligning multiple stakeholder perception of visual and auditory communication elements, Journal of Destination Marketing \& Management 7. PP. 112-130. Journal homepage: www.elsevier.com/locate/jdmm.
Labrecque, L.I., Milne, G.R., (2012). Exciting red and competent blue: the importance of color in marketing. J. Acad. Mark. Sci. 40 (5), 711-727.

Labroo, A., Kim, S., (2009). The "instrumentality" heuristic: why metacognitive difficulty is desirable during goal pursuit. Psychol. Sci. 20 (1), 127-134.

Lindstrom, M. (2005). Broad sensory branding. Journal of Product and Brand Management, 14(2), 84-87.

Luffarelli, J., Stamatogiannakis, A., Yang, H. (2018). The visual asymmetry effect: interplay of logo design and brand personality on brand equity. J. Mark. Res. https://doi.org/10.1509/jmr.15.0227.

Lusensky, J. (2010). Sounds like branding. Stockholm: Norstedts.

Mahmood, A; Luffarelli, J; Mukesh, M. (2019). What's in a logo? The impact of complex visual cues in equity crowdfunding, Journal of Business Venturing 34 .PP.41-62.

McDonald, J., (2014). Kruskal-Wallis test. Handbook of Biological Statistics, 3rd Ed., Sparky House Publishing, Baltimore, Maryland.

Michael, I., Armstrong, A., Badran, B., \& King, B. (2011). Dubai outbound tourism: An exploratory study of Emiratis and expatriates. Journal of Vacation Marketing, 17 (1), 83-91.

O'Shaughnessy, J., \& O'Shaughnessy, N. J. (2000). Treating the nation as a brand: Some neglected issues. Journal of Macro Marketing, 20(1), 56-64.

Orth, U.R., Crouch, R.C. (2014). Is beauty in the aisles of the retailer? Package processing in visually complex contexts. J. Retail. 90 (4), 524-537.

Palghat, V.K. (2009). Hearing, remembering, and branding: Guidelines for creating sonic logos, PP.47. Available: 〈http://etd.ohiolink.edu/view.cgi/Krishnan\%20Palg hat\%20Vijaykumar.pdf?acc_num1/4ucin 124284868 3) [Accessed 18.09.2020].

Scheaf. D.J., Davis, B.C., Webb, J.W., Coombs, J.E., Borns, J., Holloway, G. (2018). Signals' flexibility and interaction with visual cues: insights from crowdfunding. J. Bus. Ventur, 7-11. Available: https://doi.org/10.1016/j.jbusvent. [Accessed 15.10.2020].

Stamatogiannakis, A., Luffarelli, J., Yang, H. (2015). How to use visual design to boost brand equity. In: Batra, R., Brei, D., Seifert, C. (Eds.), the Psychology of Design: Creating Consumer Desire. M.F. Sharpe Inc PP.34-39.

Sundar, A., Kellaris, J.J., (2017). How logo colors influence shoppers' judgments of retailer ethicality: the mediating role of perceived eco-friendliness. J. Bus. Ethics 146 (3), 685-701.

Townsend, C., Shu, S.B., 2010. When and how aesthetics influences financial decisions. J. Consum. Psychol. 20 (4), 452-458.

van der Lans, R., Cote, J.A., Cole, C.A., Leong, S.M., Smits, A., Henderson, P.W., Bluemelhuber, C., Bottomley, P.A., Doyle, J.R., Fedorikhin, A., 
Mouthy, J. (2009). Cross-national logo evaluation analysis: an individual-level approach. Mark. Sci. 28 (5), 968-985.

Yorkston, E., \& Menon, G. (2004). A sound idea: Phonetic effects of brand names on consumer judgments. Journal of Consumer Research, 31(1), 4351.

Zhao, X., Lynch Jr., J.G., Chen, Q. (2010). Reconsidering Baron and Kenny: myths and truths about mediation analysis. J. Consum. Res. 37 (2), 197-206. 